\title{
BIOAKTIVITAS EKSTRAK UMBI GADUNG DAN MINYAK NYAMPLUNG SEBAGAI PENGENDALI HAMA ULAT KANTONG (Pteroma plagiophleps Hampson)
}

\author{
(Bioactivities of 'Gadung' Tuber Extractand 'Nyamplung' Oil Biopesticides \\ as Pest Control for Pteroma plagiophleps Hampson) \\ Sri Utami ${ }^{1)}$ dan/and Noor Farikhah Haneda ${ }^{2)}$ \\ ${ }^{1)}$ Balai Penelitian Kehutanan Palembang \\ Jl. Kol. H. Burlian Km. 6,5 Punti Kayu Po Box. 179, Palembang, Sumatera Selatan \\ Telp./Fax. 0711-414864 \\ ${ }^{2)}$ Fakultas Kehutanan Institut Pertanian Bogor \\ Kampus Darmaga, Jl. Raya Darmaga, Bogor
}

Naskah masuk : 6 Februari 2012; Naskah diterima : 30 November 2012

\begin{abstract}
One of the problems in silviculture of 'kayu bawang' (Dysoxylum mollissimum Blume) is 'ulat kantong' (Pteroma plagiophleps) attack. The pest may cause plant mortality and yield loss. Controlling techniques are urgent to do, such as use biopesticide. This study aimed to determine lethal, insect growth regulator and antifeedant effects of extract of 'gadung' (Dioscorea sp.) tuber and 'nyamplung' (Calophyllum inophyllum L.) oil on P. plagiophleps. The results showed that 'gadung' tuber extractand 'nyamplung' oil affected the pest mortalities, growth inhibitory and antifeedant significantly. The extract of 'gadung'tuber is more effective to feeding inhibition on $\underline{\text { P. plagiophleps than }}$ 'nyamplung' oil. Lethal concentrate of $50 \%\left(L C_{50}\right)$ on P. plagiophleps was obtained in $0.86 \%$ of extract of 'gadung' tuber. $L C_{50}$ on P. plagiophleps was found in $0.13 \%$ of 'nyamplung' oil. The success of pupa establishment on P. plagiophlepsin extract of 'gadung' tuber and 'nyamplung' oil treatments of $1.5 \%$ were $33.33 \%$ and $0 \%$, respectively.

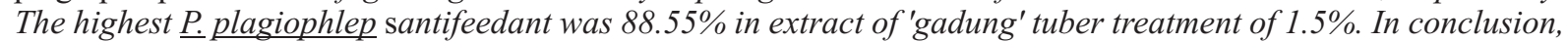
chemical compounds of 'gadung' tuber and 'nyamplung' oil caused insecticidal effects on P. plagiophleps.
\end{abstract}

Keywords: Nyamplung' oil, Pteroma plagiophleps, 'gadung'tuber

\begin{abstract}
ABSTRAK
Salah satu permasalahan yang dihadapi dalam budidaya kayu bawang (Dysoxylum mollissimum Blume) adalah serangan hama ulat kantong (Pteroma plagiophleps). Serangan hama yang berat bisa mengakibatkan kematian tanaman dan kehilangan hasil. Oleh karena itu perlu dilakukan tindakan pencegahan dan pengendalian, diantaranya dengan penggunaan insektisida nabati. Tujuan penelitian ini adalah untuk mengkaji bioaktivitas ekstrak umbi gadung (Dioscorea sp.) dan minyak nyamplung (Calophyllum inophyllum L.) dalam mengendalikan hama ulat kantong (P. plagiophleps) pada skala laboratorium. Hasil penelitian menunjukkan bahwa ekstrak umbi gadung dan minyak nyamplung memberikan pengaruh yang nyata terhadap mortalitas larva, penghambatan perkembangan serangga hama dan penghambatan aktivitas makan. Ekstrak umbi gadung lebih efektif dalam menghambat aktivitas makan ulat kantong dibandingkan minyak nyamplung, sedangkan minyak nyamplung lebih efektif dalam menyebabkan mortalitas dan menghambat perkembangan serangga hama. Besarnya nilai $\mathrm{LC}_{50}$ ekstrak umbi gadung dan minyak nyamplung masing-masing sebesar $0,86 \%(\mathrm{w} / \mathrm{v})$ dan $0,13 \%(\mathrm{w} / \mathrm{v})$. Persentase pembentukan pupa terendah pada perlakuan ekstrak umbi gadung dan minyak nyamplung konsentrasi $1,5 \%$ masing-masing sebesar $33,33 \%$ dan $0 \%$, penghambatan aktivitas makan tertinggi pada ekstrak umbi gadung konsentrasi 1,5\% yaitu sebesar $88,55 \%$. Senyawa kimia yang terkandung di dalam ekstrak umbi gadung dan minyak nyamplung diduga mempunyai efek pestisidal terhadap ulat kantong.
\end{abstract}

Kata kunci : Minyak nyamplung, Pteroma plagiophleps, umbi gadung 


\section{PENDAHULUAN}

\section{A. Latar Belakang}

Kayu bawang (Dysoxylum mollissimum Blume) merupakan jenis andalan lokal Provinsi Bengkulu yang tersebar hampir di seluruh kabupaten di Provinsi Bengkulu. Tanaman ini mempunyai serat kayu yang halus dan biasa dimanfaatkan masyarakat sebagai furniture dan konstruksi bangunan. Salah satu permasalahan yang dihadapi dalam budidaya jenis ini adalah serangan hama. Ulat kantong (Pteroma plagiophleps) merupakan salah satu jenis hama yang menyerang tanaman kayu bawang baik pada skala persemaian maupun lapangan (Utami dan Kurniawan, 2010). Hama ini mulai menyerang bibit kayu bawang umur 3 bulan di persemaian. Ulat kantong menyerang tegakan kayu bawang sejak umur 1 tahun sampai 7 tahun di lapangan. Hama ini menyerang bagian daun dan kulit batang. Serangan yang berat dapat mengakibatkan kematian tanaman.

Berdasarkan uraian tersebut, maka potensi kerusakan tanaman akibat serangan hama ulat kantong memerlukan tindakan pencegahan dan pengendalian mutlak perlu dilakukan. Penggunaan pestisida nabati merupakan teknik pengendalian hama yang ramah lingkungan dan aman bagi pengguna. Berbeda dengan pengendalian menggunakan pestisida kimia, apabila tidak dilakukan secara bijak maka dapat menimbulkan beragam dampak negatif diantaranya timbulnya resistensi hama, resurgensi hama, ledakan hama sekunder, dan dapat mencemari lingkungan.

Pestisida nabati merupakan pestisida yang bahan aktifnya berasal dari tumbuhan atau bagian tumbuhan seperti akar, daun, batang, atau buah. Pestisida nabati sebenarnya sudah lama digunakan. Sejak budidaya pertanian dilakukan secara tradisional, petani di seluruh dunia sudah terbiasa memakai bahan yang tersedia di alam untuk mengendalikan organisme penganggu tanaman.

Umbi gadung (Dioscorea sp.) dan minyak nyamplung (C. Inophyllum) merupakan 2 (dua) contoh pestisida nabati. Jenis tanaman ini banyak ditemukan di beberapa daerah di Indonesia. Masyarakat etnis di daerah Rejang Lebong (Provinsi Bengkulu), Desa Guguk Kabupaten Merangin (Provinsi Jambi), dan Desa Koto Melintang (Kabupaten Agam, Provinsi Sumatera Barat) sudah lama memanfaatkan umbi gadung sebagai pengendali hama (pengusir ulat dan racun ikan). Kardinan (2005) melaporkan bahwa umbi gadung dapat juga dipakai sebagai rodentisida de- ngan mencampur dalam umpan yang berupa pakan untuk tikus.

Demikian pula halnya minyak nyamplung (C. inophyllum L.) yang banyak dijumpai di Sumatera (Sumatera Barat, Riau, Jambi, Sumatera Selatan, Lampung), Jawa, Kalimantan (Kalimantan Barat dan Kalimantan Tengah), Sulawesi, Maluku, Nusa Tenggara Timur, dan Papua selain dimanfaatkan sebagai biodisel juga berpotensi digunakan sebagai pestisida nabati (Hadi, 2009). Oleh karena itu pada penelitian ini dua jenis ekstrak (ekstrak umbi gadung dan minyak nyamplung) dimanfaatkan sebagai materi untuk mengendalikan hama ulat kantong yang menyerang tanaman kayu bawang.

\section{B. Tujuan Penelitian}

Penelitian ini bertujuan untuk mengkaji bioaktivitas ekstrak umbi gadung dan minyak nyamplung dalam mengendalikan hama ulat kantong (P. plagiophleps) pada skala laboratorium.

\section{BAHAN DAN METODE}

\section{A. Tempat dan Waktu}

Penelitian dilakukan di Laboratorium Perlindungan Hutan Balai Penelitian Kehutanan Palembang mulai bulan Mei sampai November 2011.

\section{B. Bahan dan Alat}

Bahan-bahan yang digunakan yaitu umbi gadung, minyak nyamplung, ulat kantong, daun kayu bawang, alkohol, metanol, aseton, aquades, latron 77 0,1\%, dan kertas saring. Alat-alat yang digunakan yaitu cawan petri, saringan, gelas piala, erlenmeyer, pinset, mikroskop dan kamera.

\section{Metode}

\section{Pembuatan ekstrak}

Ekstrak yang dibuat hanya umbi gadung, sedangkan minyak nyamplung diperoleh dari Laboratorium Perlindungan Hutan Fakultas Kehutanan IPB. Umbi gadung diperoleh dengan menggali beberapa umbi gadung yang terdapat di sekitar pertanaman kayu bawang di Kawasan Hutan Dengan Tujuan Khusus (KHDTK) Kemampo, Kabupaten Banyuasin, Provinsi Sumatera Selatan. Umbi gadung yang diperoleh dari lapangan dikupas dan dicacah kemudian dikeringanginkan. Cacahan umbi gadung yang sudah kering diblender sampai menjadi tepung. Tepung 
yang terbentuk selanjutnya direndam dalam metanol selama 24 jam dengan perbandingan $1: 10$ $(\mathrm{w} / \mathrm{v})$. Hasil rendaman disaring dan ekstrak kasar tersebut digunakan sebagai ekstrak uji.

\section{Pengambilan sampel serangga uji}

Serangga uji yang digunakan yaitu ulat kantong, yang diperoleh dari pertanaman kayu bawang yang berumur 1 tahun di KDHTK Kemampo Kabupaten Banyuasin Provinsi Sumatera Selatan, tegakan kayu bawang yang berumur 7-9 tahun di Desa Kampung Delima Kabupaten Rejang Lebong dan Desa Lubuk Saung Kabupaten Kepahiang Provinsi Bengkulu. Larva yang diperoleh dari lapangan sebagian besar instar akhir. Larva tersebut dipelihara sampai menjadi pupa dan imago. Kemudian larva instar awal (ukurannya seragam dengan pertimbangan sampai saat ini belum diketahui stadia larva $P$. plagiophleps) yang dibiakkan digunakan sebagai serangga uji.

\section{Uji efikasi ekstrak}

\section{a. Uji mortalitas}

Konsentrasi yang digunakan untuk pengujian larva ulat kantong yaitu $0,125 \%$; $0,25 \%$; $0,5 \% ; 1 \% ; 1,5$; dan kontrol dengan pelarut metanol-aseton ditambah pengemulsi (Latron 77 $0,1 \%$ ) dengan perbandingan $1: 1$. Setiap konsentrasi diuji sebanyak 3 ulangan dengan 15 ekor larva untuk setiap ulangannya. Metode yang digunakan yaitu kombinasi metode residu pada daun dan metode kontak serangga/penyemprotan. Rancangan percobaannya adalah rancangan acak lengkap (RAL).

Daun kayu bawang (sebagai pakan) yang digunakan untuk setiap ulangan sebanyak 3 helai daun. Permukaan daun pakan diolesi larutan ekstrak sebanyak $50 \mu 1$ dan sisa larutan sebanyak $\pm 20 \mu \mathrm{l}$ disemprotkan pada larva uji. Setelah pelarutnya menguap, daun pakan diletakkan dalam cawan petri yang telah dialasi tisu. Pada setiap cawan petri diletakkan 15 ekor ulat kantong. Ulat kantong kontrol diberi pakan daun yang hanya diolesi metanol. Pemberian pakan daun perlakuan dilakukan selama 48 jam, kemudian larva diberi pakan daun segar tanpa perlakuan.

Data kematian dihitung dalam persen kematian dengan rumus sebagai berikut :

Persentase Kematian Larva $\frac{\Sigma \text { Larva yang mati }}{\Sigma \text { Total larva }} \times 100 \%$

Menurut Prijono (1998), aktivitas insektisida ekstrak diklasifikasikan dalam beberapa kategori yaitu : 1) aktivitas kuat: mortalitas (m) $\geq 95 \%, 2$ ) agak kuat : $75 \% \leq \mathrm{m}<95 \%, 3$ ) cukup kuat : $60 \% \leq \mathrm{m}<75 \%$, 4) sedang : $40 \% \leq \mathrm{m}$ $<60 \%, 5$ ) agak lemah : $25 \% \leq \mathrm{m}<40 \%, 6$ ) lemah $: 5 \% \leq \mathrm{m}<25 \%, 7)$ tidak aktif: $\mathrm{m}<5 \%$.

\section{b. Uji penghambatan perkembangan serangga}

Uji ini merupakan kelanjutan dari uji mortalitas. Larva yang masih hidup (pada uji mortalitas) diamati perkembangannya sampai menjadi pupa dan imago. Persentase keberhasilan pembentukan pupa dihitung dengan menggunakan rumus sebagai berikut:

Persentase Pembentukan Pupa $\frac{\Sigma \text { pupa yang terbentuk }}{\Sigma \text { larva yang hidup }} \times 100 \%$

Sedangkan persentase keberhasilan pembentukan imago dihitung dengan menggunakan rumus sebagai berikut :

Persentase Pembentukan Imago $\frac{\Sigma \text { imago yang muncul }}{\Sigma \text { larva yang hidup }} \times 100 \%$

\section{c. Uji penghambatan makan}

Konsentrasi yang digunakan sama dengan uji mortalitas larva. Metode yang digunakan yaitu metode non pilihan. Rancangan percobaan yang digunakan yaitu RAL Faktorial, dengan perlakuan jenis ekstrak dan konsentrasi ekstrak. Daun pakan sebanyak 3 helai daun kayu bawang diletakkan pada cawan petri yang dialasi tisu, kemudian ke dalamnya dimasukkan 15 ekor ulat kantong. Setiap perlakuan diuji sebanyak 3 ulangan. Setelah 48 jam daun perlakuan diambil dan dikeringkan dalam oven pada suhu $100^{\circ} \mathrm{C}$ selama 48 jam untuk mengetahui berat kering akhir dan dihitung berat/bobot daun yang dimakan.

Penentuan kadar air daun, 2 lempeng daun dari masing-masing daun dikeringkan dalam oven pada suhu $100^{\circ} \mathrm{C}$ selama 48 jam. Menurut Haygreen dan Bowyer (1989) perhitungan kadar air menggunakan rumus sebagai berikut:

Kadar air $\frac{\text { Berat basah - berat kering }}{\text { Berat kering }} \times 100 \%$

Berat kering awal $\frac{\text { Berat kering daun contoh }}{\text { Berat basah daun contoh }}$ Berat basah daun

Berat daun yang dimakan $=$ Berat kering awal Berat kering akhir

$\mathrm{F} 1=\left(1-\frac{\text { Berat perlakuan yang dimakan }}{\text { Berat kontrol yang dimakan }}\right) \times 100 \%$

$\mathrm{FI}=$ Feeding Inhibition 


\section{Analisis data}

Data hubungan antara mortalitas larva uji dengan konsentrasi ekstrak diolah dengan analisis probit (Finney, 1971, dalam Dadang dan Prijono, 2008) menggunakan program PoloPlus (Robertson et al., 2003). Sedangkan data perkembangan larva sampai menjadi imago dan penghambatan aktivitas makan diolah dengan sidik ragam ANOVA dan nilai tengah diuji Duncan dengan program SAS versi 6(SAS Institute, 1990).

\section{HASIL DAN PEMBAHASAN}

\section{A. Hasil}

\section{Pengaruh Ekstrak Umbi Gadung dan Minyak Nyampung terhadap Mortalitas Hama}

Hasil analisis statistik menunjukkan bahwa ekstrak umbi gadung dan minyak nyamplung memberikan pengaruh yang signifikan terhadap mortalitas ulat kantong (Tabel 1). Terdapat korelasi positif antara konsentrasi ekstrak dengan mortalitas larva. Semakin tinggi konsentrasi ekstrak maka semakin tinggi tingkat mortalitas larva. Pada konsentrasi tertinggi, ekstrak umbi gadung dan minyak nyamplung menyebabkan mortalitas larva masing-masing sebesar $97,78 \%$ dan $100 \%$. Menurut klasifikasi aktivitas ekstrak, kedua jenis insektisida nabati tersebut mempunyai aktivitas kuat. Pada konsentrasi terendah $(0,125 \%)$, persentase mortalitas larva perlakuan ekstrak umbi gadung dan minyak nyamplung masing-masing 64,44\% (aktivitas cukup kuat) dan 55,56\% (aktivitas sedang). Sedangkan pada kontrol, persentase mortalitas larva perlakuan umbi gadung sebesar $2,22 \%$ dan perlakuan minyak nyamplung tidak ada larva yang mati sama sekali.

Gejala kematian larva $P$. plagiophleps yaitu larva yang terdapat di dalam kantong tidak bergerak sama sekali dan kantongnya membuka, sebagian tubuh larva yang keluar dari kantong lunak dan berwarna kecokelatan seperti yang terlihat pada Gambar 1a. Pada sebagian larva $P$. plagiophleps yang mati ditandai juga adanya kantong yang menutup. Pada Gambar $1 b$ yang sebelah kanan adalah larva yang dikeluarkan dari kantongnya dan hidup, sedangkan sebelah kiri adalah larva yang mati. Sangat jelas terlihat bahwa larva yang mati ukurannya mengecil dan berwarna kecokelatan, sedangkan larva yang hidup berwarna putih kecokelatan dengan ukuran lebih besar dan aktif bergerak.

Pada Gambar 2 menunjukkan bahwa persentase mortalitas ulat kantong paling besar terjadi pada hari pertama setelah pelakuan. Persentase mortalitas semakin menurun dengan semakin bertambahnya hari dan pada hari ketujuh tidak dijumpai lagi kematian ulat kantong. Pada hari pertama dan kedua setelah perlakuan, ekstrak kasar konsentrasi tertinggi menyebabkan tingkat mortalitas lebih besar dibandingkan konsentrasi lainnya. Sedangkan pada perlakuan ekstrak umbi gadung konsentrasi paling rendah $(0,125 \%)$ pada hari keenam setelah perlakuan masih dijumpai larva yang mati. Hal tersebut menunjukkan bahwa waktu efektif yang dibutuhkan untuk mengendalikan hama ulat kantong yaitu berkisar 1-2 hari pada taraf konsentrasi $0,25-1,5 \%$.

Demikian halnya dengan ekstrak umbi gadung, pengaruh toksik minyak nyamplung terhadap ulat kantong juga terjadi sampai hari kedua setelah perlakuan.

Tabel(Table) 1. Rata-rata persentase mortalitas ulat kantong pengaruh perlakuan ekstrak umbi gadung dan minyak nyamplung (Mean of mortality percentage on $\underline{P}$. plagiophleps affected by 'gadung'tuber extract and 'nyamplung' oil)

\begin{tabular}{|l|c|c|}
\hline \multirow{2}{*}{$\begin{array}{c}\text { Konsentrasi (Concentrate) } \\
(\% / \mathrm{v} / \mathrm{w})\end{array}$} & \multicolumn{2}{|c|}{ Persentase Mortalitas (Mortality Percentage) $(\%))^{\mathrm{a}}$} \\
\cline { 2 - 3 } & $\begin{array}{c}\text { Umbi Gadung } \\
\text { (Extract of 'gadung'tuber })\end{array}$ & $\begin{array}{c}\text { Minyak Nyamplung } \\
\text { ('Nyamplung'oil) }\end{array}$ \\
\hline Kontrol (Control) & $2,22 \mathrm{a}$ & $0,00 \mathrm{a}$ \\
\hline 0,125 & $64,44 \mathrm{~b}$ & $55,56 \mathrm{a}$ \\
\hline 0,25 & $71,11 \mathrm{bc}$ & $62,22 \mathrm{~b}$ \\
\hline 0,5 & $75,56 \mathrm{c}$ & $95,55 \mathrm{c}$ \\
\hline 1 & $95,56 \mathrm{~d}$ & $95,55 \mathrm{c}$ \\
\hline 1,5 & $97,78 \mathrm{~d}$ & $100 \mathrm{c}$ \\
\hline
\end{tabular}

Keterangan (Remarks) : Rataan pada kolom yang sama pada setiap jenis ekstrak yang diikuti oleh huruf yang sama tidak berbeda nyata berdasarkan uji selang berganda Duncan pada taraf nyata 5\% (The average in the same column followed by the same letters is not significant based on Duncan's Multiple Range Test, $\alpha=5 \%$ ) 


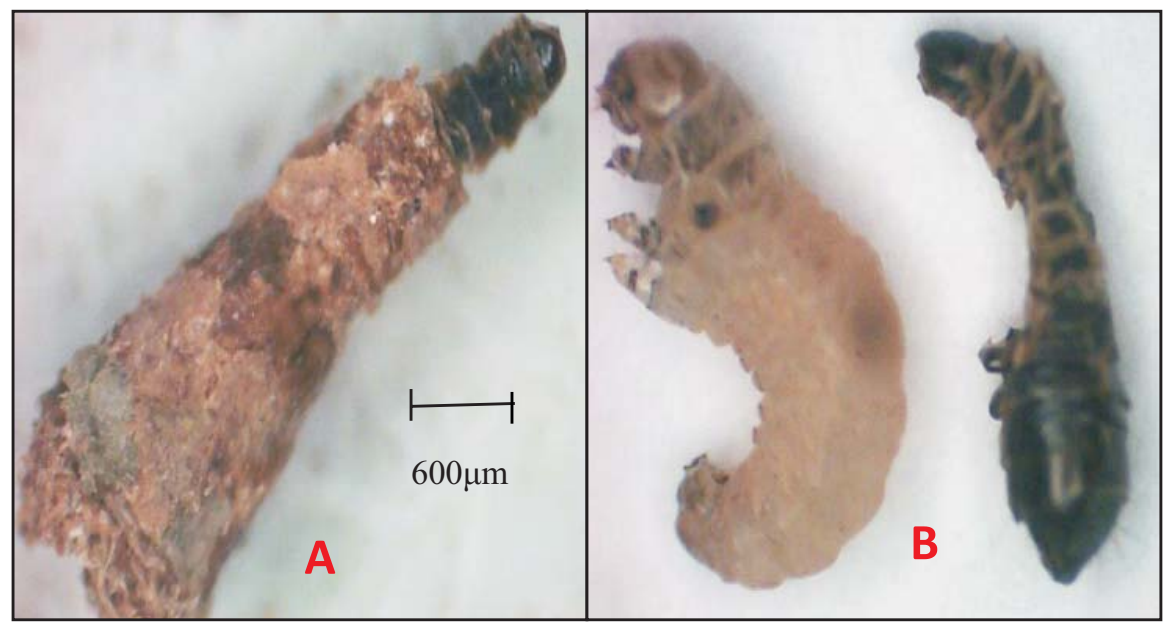

Gambar(Figure) 1. a) Ulat kantong yang mati (The dead larvae), b) Larva yang hidup dan mati (Larvae and the dead larvae)

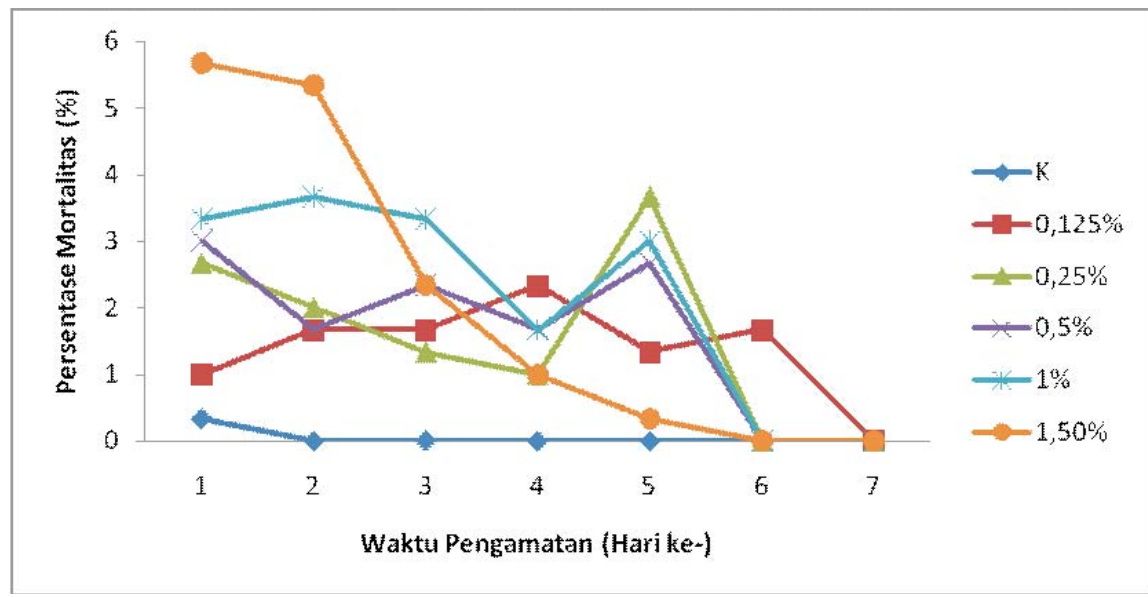

Gambar(Figure) 2. Rata-rata persentase mortalitas larva perlakuan ekstrak umbi gadung pada berbagai

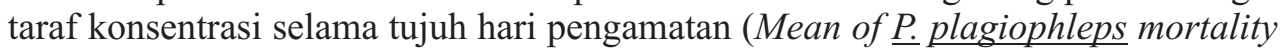
observed for seven days on extract treatment of'gadung'tuber)

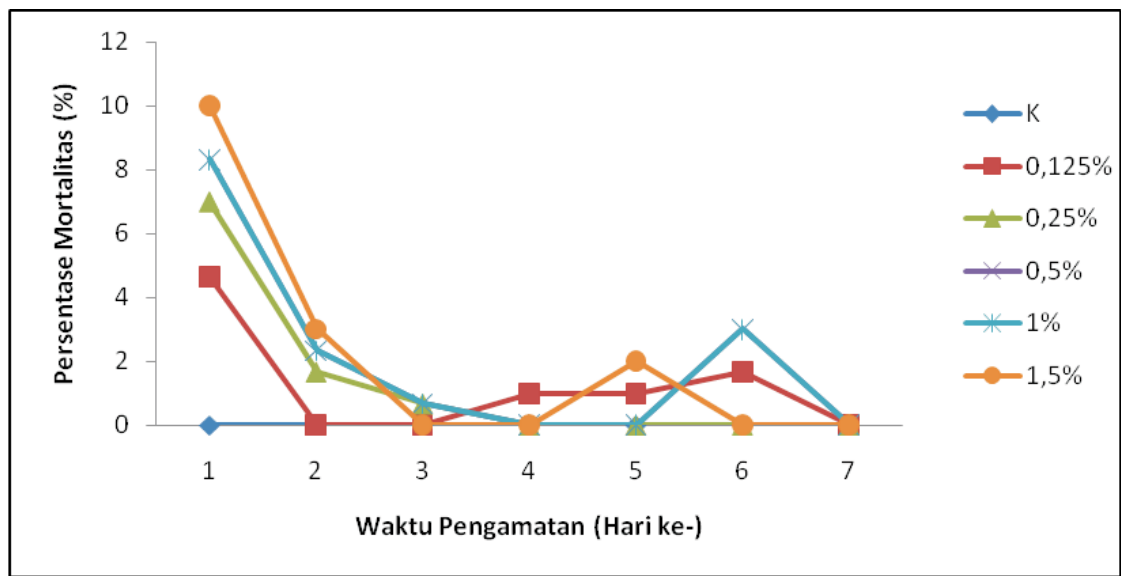

Gambar(Figure) 3. Rata-rata persentase mortalitas larva perlakuan minyak nyamplung pada berbagai taraf konsentrasi selama tujuh hari pengamatan (Mean of $\underline{\text { P. plagiophleps }}$ mortality observed for seven days on 'nyamplung' oil treatment) 
Tabel(Table) 2. Penduga parameter toksisitas ekstrak umbi gadung dan minyak nyamplung terhadap $P$. plagiophleps (Parameter estimators toxicity of tuber 'gadung'extract and 'nyamplung' oil against larvae $\underline{\text { P. plagiophleps })}$

\begin{tabular}{|l|c|c|c|c|}
\hline Ekstrak Uji (Sample Extracts) & $a \pm \mathrm{GB}^{\mathrm{a})}$ & $b \pm \mathrm{GB}^{\mathrm{a})}$ & $\mathrm{LC}_{50}$ & $\mathrm{LC}_{95}$ \\
\hline $\begin{array}{l}\text { Umbi gadung ( extract of } \\
\text { tuber 'gadung') }\end{array}$ & $1,44 \pm 0,17$ & $1,35 \pm 0,28$ & 0,86 & 1,42 \\
\hline $\begin{array}{l}\text { Minyak nyamplung } \\
\text { ('Nyamplung' oil) }\end{array}$ & $1,93 \pm 0,23$ & $2,15 \pm 0,35$ & 0,13 & 0,74 \\
\hline
\end{tabular}

Keterangan (Remarks) : $a=$ intersep regresi probit, $b=$ kemiringan regresi probit, $\mathrm{GB}=$ galat baku, $\mathrm{SK}=\operatorname{selang} \operatorname{kepercayaan}(a=$ intercept of probitregression, $b=$ slope of probitregression, $G B=$ standard deviation, $S K=$ confidence interval)

Akan tetapi pada hari-hari berikutnya terjadi penurunan persentase mortalitas yang lebih besar dibandingkan dengan ekstrak umbi gadung (Gambar 3). Pada pengamatan hari ketujuh setelah perlakuan, tidak lagi dijumpai kematian larva.

Berdasarkan nilai $\mathrm{LC}_{50}$ pada perlakuan minyak nyamplung 6,62 kali lebih toksik dibandingkan dengan ekstrak umbi gadung (Tabel 2). Sedangkan pada $\mathrm{LC}_{95}$ pada minyak nyamplung lebih toksik 1,92 kali dibandingkan dengan ekstrak umbi gadung. Pada minyak nyamplung konsentrasi $0,13 \%$ dan $0,74 \%$ bias menyebabkan mortalitas larva masing-masing sebesar 50\% dan 95\%. Sedangkan pada ekstrak umbi gadung konsentrasi $0,86 \%$ menyebabkan mortalitas ulat kantong sebesar $50 \%$, dan konsentrasi $1,42 \%$ menyebabkan kematian sebesar 95\%. Hal ini bisa dija- dikan acuan dalam pengendalian hama P. plagiophleps.

\section{Pengaruh Ekstrak Umbi Gadung dan Minyak Nyampung terhadap Keberhasil- an Pembentukan Pupa dan Imago}

Hasil analisis statistik menunjukkan minyak nyamplung memberikan pengaruh yang signifikan terhadap persentase pembentukan pupa. Persentase pembentukan pupa pada kontrol sebesar 95,55\%, sedangkan pada konsentrasi tertinggi tidak dijumpai pupa sama sekali (Tabel 3). Pada perlakuan ekstrak umbi gadung, persentase pembentukan pupa pada konsentrasi 1 dan 1,5\% sebesar $33,33 \%$. Hal tersebut di atas menunjukkan bahwa pada konsentrasi yang sama, minyak nyamplung lebih memberikan pengaruh yang kuat dalam menghambat pembentukan pupa dibandingkan dengan ekstrak umbi gadung.

Tabel(Table) 3. Persentase pembentukan pupa respon aplikasi ekstrak umbi gadung dan minyak nyamplung (Percentage of pupa establishment caused by extract treatmentof 'gadung' tuber and 'nyamplung' oil)

\begin{tabular}{|c|c|c|}
\hline \multirow{2}{*}{$\begin{array}{c}\text { Konsentrasi } \\
\text { Concentrate }) \\
(\%)\end{array}$} & \multicolumn{2}{|c|}{$\begin{array}{c}\text { Persentase Pembentukan pupa } \\
\text { (Percentage of Pupa establishment) (\%) })^{\mathrm{a}}\end{array}$} \\
\cline { 2 - 3 } & $\begin{array}{c}\text { Umbi gadung } \\
\text { (Extract of 'gadung'tuber) }\end{array}$ & $\begin{array}{c}\text { Minyak nyamplung } \\
\text { ('Nyamplung' oil) }\end{array}$ \\
\hline Kontrol (control) & 100,00 & $95,55 \mathrm{a}$ \\
\hline 0,125 & 44,44 & $11,11 \mathrm{~b}$ \\
\hline 0,25 & 53,33 & $4,17 \mathrm{~b}$ \\
\hline 0,5 & 70,00 & $6,67 \mathrm{~b}$ \\
\hline 1 & 33,33 & $16,67 \mathrm{~b}$ \\
\hline 1,5 & 33,33 & $0,00 \mathrm{~b}$ \\
\hline
\end{tabular}

Keterangan (Remarks) : Rataan pada kolom yang sama pada setiap jenis ekstrak yang diikuti oleh huruf yang sama tidak berbeda nyata berdasarkan uji selang berganda Duncan pada taraf nyata $5 \%$ (The average in the same column followed by the same letters is not significant based on Duncan's Multiple Range Test, $\alpha=5 \%$ ) 
Tabel(Table) 4. Persentase pembentukan imago pengaruh aplikasi ekstrak umbi gadung dan minyak nyamplung (Percentage of imago establishment caused by treatment of extract of 'gadung' tuber and 'nyamplung' oil)

\begin{tabular}{|c|c|c|}
\hline \multirow{2}{*}{$\begin{array}{c}\text { Konsentrasi } \\
\text { (Concentrate) } \\
(\%)\end{array}$} & \multicolumn{2}{|c|}{$\begin{array}{c}\text { Persentase Pembentukan imago } \\
\text { (Percentage of imago establishment) (\%) }\end{array}$} \\
\cline { 2 - 3 } & $\begin{array}{c}\text { Umbi gadung } \\
\text { Minyak nyamplung } \\
\text { ('Nyamplung'oil) }\end{array}$ \\
\hline Kontract of 'gadung'tuber) & $100 \mathrm{a}$ & $00 \mathrm{a}$ \\
\hline 0,125 & $0,00 \mathrm{~b}$ & $0,00 \mathrm{~b}$ \\
\hline 0,25 & $0,00 \mathrm{~b}$ & $0,00 \mathrm{~b}$ \\
\hline 0,5 & $0,00 \mathrm{~b}$ & $0,00 \mathrm{~b}$ \\
\hline 1 & $0,00 \mathrm{~b}$ & $0,00 \mathrm{~b}$ \\
\hline 1,5 & $0,00 \mathrm{~b}$ & $0,00 \mathrm{~b}$ \\
\hline
\end{tabular}

Keterangan (Remarks) : Rataan pada kolom yang sama pada setiap jenis ekstrak yang diikuti oleh huruf yang sama tidak berbeda nyata berdasarkan uji selang berganda Duncan pada taraf nyata $5 \%$ (The average in the same column followed by the same letters is not significant based on Duncan's Multiple Range Test, $\alpha=5 \%$ )

Tabel 4 menyajikan pengaruh ekstrak terhadap persentase pembentukan pupa. Hasil penelitian menunjukkan bahwa dari beberapa pupa yang terbentuk semuanya tidak ada yang berhasil berkembang menjadi imago pada semua taraf konsentrasi baik pada perlakuan ekstrak umbi gadung maupun minyak nyamplung. Se-dangkan pada kontrol, keberhasilan pembentuk-an imago sebesar $100 \%$.

\section{Pengaruh Ekstrak Umbi Gadung dan Minyak Nyampung terhadap Penghambatan Akti- vitas Makan Hama}

Analisis statistik menunjukkan bahwa kedua jenis ekstrak memberikan pengaruh yang signifikan terhadap penghambatan aktivitas ma- kan ulat kantong (Tabel 5). Konsentrasi ekstrak berkorelasi positif terhadap besarnya penghambatan aktivitas makan. Semakin tinggi konsentrasi ekstrak, semakin kuat juga pengaruh ekstrak tersebut dalam menghambat aktivitas makan ulat kantong. Ekstrak umbi gadung memberikan pengaruh lebih kuat dalam menghambat aktivitas makan ulat kantong. Pada konsentrasi terendah, persentase penghambatan aktivitas makan ulat kantong pada perlakuan ekstrak umbi gadung dan minyak nyamplung masing-masing sebesar $24,12 \%$ dan $15,50 \%$. Sedangkan pada konsentrasi tertinggi, besarnya penghambatan aktivitas makan pada ekstrak umbi gadung dan minyak nyamplung masing-masing sebesar $88,55 \%$ dan $71,23 \%$.

Tabel(Table) 5. Persentase penghambatan aktivitas makan P. plagiophleps pengaruh aplikasi ekstrak umbi gadung dan minyak nyamplung (Percentage of the feeding inhibition on $\underline{P}$. plagiophleps caused by treatment of extract of 'gadung'tuber and 'nyamplung' oil)

\begin{tabular}{|c|c|c|}
\hline \multirow{2}{*}{$\begin{array}{c}\text { Konsentrasi } \\
\text { Concentrate }) \\
(\%)\end{array}$} & \multicolumn{2}{|c|}{$\begin{array}{c}\text { Persentase Penghambatan Aktivitas Makan Ulat kantong } \\
\text { (Percentage of the FeedingInhibition on P. plagiophleps) }\end{array}$} \\
\cline { 2 - 3 } & $\begin{array}{c}\text { Umbi Gadung } \\
\text { (Extract of 'gadung' tuber) }\end{array}$ & $\begin{array}{c}\text { Minyak Nyamplung } \\
\text { ('Nyamplung'oil) }\end{array}$ \\
\hline Kontrol (Control) & $0,00 \mathrm{a}$ & $0,00 \mathrm{a}$ \\
\hline 0,125 & $24,12 \mathrm{a}$ & $15,50 \mathrm{ab}$ \\
\hline 0,25 & $28,24 \mathrm{ab}$ & $17,71 \mathrm{ab}$ \\
\hline 0,5 & $69,17 \mathrm{bc}$ & $38,08 \mathrm{bc}$ \\
\hline 1 & $70,60 \mathrm{bc}$ & $60,51 \mathrm{~cd}$ \\
\hline 1,5 & $88,55 \mathrm{c}$ & $71,23 \mathrm{~d}$ \\
\hline
\end{tabular}

Keterangan (Remarks) : Rataan pada kolom yang sama pada setiap jenis ekstrak yang diikuti oleh huruf yang sama tidak berbeda nyata berdasarkan uji selang berganda Duncan pada taraf nyata $5 \%$ (The average in the same column followed by the same letters is not significant based on Duncan's Multiple Range Test, $\alpha=5 \%$ ) 


\section{B. Pembahasan}

Kedua jenis ekstrak yaitu umbi gadung dan minyak nyamplung memberikan pengaruh yang nyata dalam menekan serangga hama ulat kantong, berpengaruh nyata terhadap mortalitas, penghambatan perkembangan serangga, dan penghambatan aktivitas makan. Setiap tanaman termasuk gadung dan nyamplung mempunyai kandungan senyawa metabolit primer dan sekunder. Senyawa metabolit sekunder inilah yang mempunyai peran sebagai pelindung tanaman dari gangguan serangga hama. Umbi gadung merupakan salah satu jenis tanaman anggota famili Dioscoreaceae, sedangkan nyamplung termasuk tanaman dari famili Guttiferae. Dadang dan Prijono (2008) melaporkan bahwa kedua jenis famili tanaman tersebut memiliki sifat insektisidal.

Umbi gadung sudah dikenal sebagai bahan pestisida nabati yang mempunyai efek pestisidal kuat. Patcharaporn et al. (2010) melaporkan bahwa tumbuhan Dioscorea hispida Dennst dapat dimanfaatkan sebagai insektisida. Lebih lanjut Kardinan (2005) mengemukakan bahwa umbi gadung (D. hispida) sangat beracun terhadap tikus, yang biasanya dipakai dengan cara mencampurnya dengan pakan dan digunakan sebagai umpan yang mematikan. Menurut Kardinan (2005), bubuk kering umbi gadung yang diekstrak dengan metanol, fraksi alkaloid sebesar $580 \mathrm{ppm}$ menyebabkan kematian sebesar $50 \%$ untuk tikus putih jantan dan 540 ppm menyebabkan kematian 50\% pada tikus betina. Kardinan (2005) melaporkan bahwa kandungan umbi gadung yang bersifat pestisidal yaitu alkaloid dioskorin, senyawa yang bersifat toksik. Santi (2010) juga melaporkan bahwa ekstrak metanol umbi gadung (D. hispida) mempunyai penghambatan aktivitas makan serangga Epi-lachna sparsa sebesar 95,65\% pada konsentrasi 10\% (b/v). Gadung jenis lain juga bersifat insek-tisidal seperti $D$. bulbifera Linn dan D. composita Dennst. D. bulbifera bersifat toksik terhadap ulat Artemia salina Leach dengan $\mathrm{Lc}_{50}$ sebesar 0,746 ppm (Puspawati, 1997), sedangkan D. composita dimanfaatkan sebagai rodentisida botanis untuk mengendalikan hama tikus sawah, diduga senyawa dioscorin yang bersifat insektisidal dan bisa dimanfaatkan sebagai obat antifertilitas yang efektif khususnya untuk hama tikus (Budiprakoso et al., 2008).

Dahlan dan Gusmailina (2006) melaporkan bahwa biji nyamplung mempunyai bahan aktif Inophylum A-E, calophylloide, dan asid calophynic. Adapun kandungan lainnya dalam jumlah kecil yaitu: 1, 2, 3, 4, 4a, 7-beksahidro-1,6 dimetil-4 (1-metilletil) naftalin, cubebene, selinene, calerene, farnesene, scadinene, bourbonene, zingiberene, copaene, murelene, sesquiphellandrene, octadecanal, heksadecane, dan farmesol (Dahlan dan Gusmailina, 2006). Diduga senyawa yang terkandung pada minyak nyamplung tersebut yang mempunyai efek pestisidal terhadap larva P. plagiophleps.

Berdasarkan nilai persentase mortalitas dan kecepatan daya bunuh terhadap serangga ulat kantong, minyak nyamplung lebih efektif dalam menyebabkan kematian larva dibandingkan ekstrak umbi gadung. Jumlah larva perlakuan minyak nyamplung banyak terjadi kematian pada hari pertama setelah perlakuan, sedangkan pada perlakuan ekstrak umbi gadung, kematian larva terjadi perlahan-lahan bahkan pada hari kelima setelah perlakuan masih terjadi kematian larva.

Berdasarkan nilai $\mathrm{Lc}_{50}$, minyak nyamplung 6,62 kali lebih toksik dibandingkan dengan ekstrak umbi gadung. Sedangkan pada $\mathrm{LC}_{95}$ minyak nyamplung lebih toksik 1,92 kali dibandingkan ekstrak umbi gadung. Hal ini bisa dijadikan acuan dalam pengendalian pada skala lapangan, dimana konsentrasi ekstrak umbi gadung dan minyak nyamplung masing-masing sebesar $0,86 \%$ dan $0,13 \%$ bisa menyebabkan kematian larva sebesar $50 \%$.

Kedua jenis ekstrak tersebut tidak hanya mempunyai efek mortalitas tetapi juga menghambat perkembangan serangga uji. Minyak nyamplung lebih menghambat perkembangan pupa $P$. plagiophleps dibandingkan dengan ekstrak umbi gadung. Konsentrasi minyak nyamplung tertinggi $(1,5 \%)$, mampu menghambat pembentukan pupa sebesar $100 \%$, sedangkan ekstrak umbi gadung hanya menghambat sebesar $67,77 \%$. Kedua jenis ekstrak tersebut juga menghambat terbentuknya imago. Hal ini mengindikasikan bahwa kedua jenis ekstrak tersebut mempunyai efek yang cukup kuat dalam menghambat perkembangan serangga hama, walaupun dari beberapa larva yang masih hidup bisa menjadi pupa akan tetapi pupa tersebut tidak berhasil membentuk imago. Dalam skala lapangan, fenomena ini sangat bermanfaat dalam mengendalikan serangga hama yang secara teknis sulit dikendalikan dan mempunyai siklus hidup yang lama.

Uraian di atas menjelaskan bahwa ternyata minyak nyamplung memiliki efek pestisidal yang lebih kuat (mortalitas dan penghambatan perkembangan serangga hama) terhadap ulat kantong dibandingkan dengan umbi gadung. Namun untuk respon penghambatan aktivitas makan ulat 
kantong, ekstrak umbi gadung lebih memiliki efek yang kuat dibandingkan dengan minyak nyamplung. Contohnya ekstrak umbi gadung pada konsentrasi $1,5 \%$ mampu menghambat aktivitas makan sebesar $88,55 \%$ sedangkan minyak nyamplung pada konsentrasi yang sama hanya menghambat sebesar 71,23\%. Dadang dan Prijono (2008) menyatakan bahwa aktivitas penghambatan makan (antifeedant) adalah zat atau senyawa kimia yang ketika dirasakan oleh serangga dapat menghasilkan penghentian aktivitas makan yang bersifat sementara atau permanen tergantung pada potensi atau kekuatan senyawa tersebut dalam memberikan aktivitasnya. Antifeedant, aksi penolakan makannya tidak harus total $100 \%$ tetapi cukup membuat tumbuhan atau tanaman tersebut kurang disukai (Perry et al., 1977).

Senyawa dioscorin (yang tergolong alkaloid) pada ekstrak umbi gadung diduga mempengaruhi penghambatan aktivitas makan serangga $P$. plagiophleps.

\section{KESIMPULAN}

1. Ekstrak umbi gadung (Dioscorea sp.) dan minyak nyamplung (Calophyllum inophyllum Linn.) memberikan pengaruh yang nyata terhadap mortalitas ulat kantong (P. plagiophleps).

2. Ekstrak umbi gadung lebih efektif dalam menghambat aktivitas makan ulat kantong dibandingkan minyak nyamplung, sedangkan minyak nyamplung lebih efektif dalam menyebabkan mortalitas dan menghambat perkembangan serangga hama.

3. Besarnya nilai $\mathrm{LC}_{50}$ ekstrak umbi gadung dan minyak nyamplung masing-masing sebesar $0,86 \%(\mathrm{w} / \mathrm{v})$ dan $0,13 \%(\mathrm{w} / \mathrm{v})$.

4. Persentase pembentukan pupa terendah pada perlakuan ekstrak umbi gadung dan minyak nyamplung konsentrasi 1,5\% masing-masing sebesar $33,33 \%$ dan $0 \%$.

5. Penghambatan aktivitas makan tertinggi pada ekstrak umbi gadung konsentrasi $1,5 \%$ yaitu sebesar $88,55 \%$.

6. Senyawa dioscorin yang terkandung di dalam ekstrak umbi gadung dan senyawa calophylloide dan asid calophynic yang terkandung pada minyak nyamplung diduga yang mempunyai efek pestisidal terhadap ulat kantong.

\section{DAFTAR PUSTAKA}

Budiprakoso, B., J. Permada, Purwanto dan A. Sifa. 2008. Pengujian Efektivitas Daun Gamal (Gliricidia sepium (Jacq.) Stend) dan Umbi Gadung (Dioscorea composita Dennst) sebagai Rodentisida Botanis untuk Alternatif Pengendalian Tikus Sawah (Rattus argentiventer Rob. \& Klo.). Laporan Akhir PKMP. Institut Pertanian Bogor. Bogor.

Dadang, D. dan Prijono. 2008. Insektisida Nabati : Prinsip, Pemanfaatan dan Pengembangan. Departemen Proteksi Tanaman. Institut Pertanian Bogor. Bogor.

Dahlan dan E. Gusmailina. 2006. Sekilas Me-ngenal Nyamplung (Calophyllum inophyllum Linn.). Ranting Warta Hasil Hutan Volume 1 Nomor 1.

Hadi, W.A. 2009. Pemanfaatan Minyak Biji Nyamplung (Calophyllum inophyllum L.) se-bagai Bahan Bakar Minyak Pengganti Solar. Jurnal Riset Daerah Vol. VIII No. 2 Agustus 2009.

Harborne, J.B. 1988. Introduction to Ecological Biochemistry. $3^{\text {rd }}$ ed. Academic Press. London.

Kardinan, A. 2005. Pestisida Nabati : Ramuan dan Aplikasi. Penebar Swadaya. Jakarta.

Panda, N. dan G.S. Khush. 1995. Host Plant Resintence to Insects. CAB International. International Rice Research Institute.

Patcharaporn, V., W. Ding, and X. Cen. 2010. Insecticidal Activity of Five Chinese Medicinal Plants againts Plutella xylostella L. Larva. Journal of Asia Pasific Entomology.

Perry, A.S., I. Yamamoto. I. Ishaaya and R.Y. Perry. 1997. Insecticides in Agriculture and Env Entomol, Retrospects and Prospect. Springer. Berlin.

Prakash, A. dan J. Rao. 1997. Botanical Pesticides in Agriculture. CRC Press. Florida.

Prijono, D. 1998. Insectisidal Activity of Meliaceous Seed Extracts Against Crocidolomia binotalis Zeller (Lepidoptera :Pyralidae).Bul HPT 10 : 1-7.

Puspawati, N.M. 1997. Extraction, Isolation and Characterisation of Biologicaly Active Compounds from Balinse Plants Use in Traditional Medicines. IAEUP - Ditjen Dikti University of Udayana.

Robertson, J.L., HK. Preisler. and RM. Russel. 2003. PoloPlus :Probit and Logit Analysis User's Guide. LeOraSoftware. El Cerrito (CA). 
Santi, S.R. 2010. Senyawa AktifAntimakan dari Umbi Gadung (Dioscorea hispida Dennst). Jurnal Kimia 4(1), Januari 2010.

SAS Institute. 1990. SAS/STAT User's Guide, Version 6, Vol. 2. Thirth ed. SAS Institute.Cary (NC).

Scott, I.M.,H.R. Jensen. R, Nicol, L. Lesage., R. Bradbury., P. Sanchez-Vindas., L. Poveda, J.T. Arnason and B.J.R Philoge'ne. 2004. Efficacy of Piper (Piperaceae) extracts for control of common home and garden insect pests. J Econ Entomol 97: 13901403.

Tjokronegoro, R.K. 1987. Penelusuran Senyawa Kandungan Tumbuhan Indonesia, Bioaktif terhadap Serangga. Disertasi. Universitas Padjajaran. Bandung.

Utami, S. dan A. Kurniawan. 2010. Budidaya Jenis Kayu bawang Aspek Perlindungan. Laporan Hasil Penelitian. Balai Penelitian Kehutanan. Palembang. 